\title{
An Explicit/Implicit Lead to Producing Requests: Eliciting Learners' Awareness or Soliciting Metapragmatic Knowledge
}

\author{
Nasim Ariana \\ Islamic Azad University No. 209. North Iranshahr St. Tehran, Iran \\ E-mail: nasimariana82@gmail.com \\ Masoumeh Ahmadi Shirazi (Corresponding author) \\ English Department, Faculty of Foreign Languages and Literatures, University of Tehran, Tehran, Iran \\ E-mail: ahmadim@ut.ac.ir \\ Seyed Mohammad Mousavi Nadoushani \\ English Department, Faculty of Foreign Languages and Literatures, University of Tehran, Tehran, Iran \\ E-mail: mo.mousavi@ut.ac.ir
}

$\begin{array}{lll}\text { Received: 03-06-2016 } & \text { Accepted: 05-09-2016 } & \text { Advance Access Published: November } 2016 \\ \text { Published: 02-01-2017 } & \text { doi:10.7575/aiac.ijalel.v.6n.1p.115 } & \text { URL: http:/dx.doi.org/10.7575/aiac.ijalel.v.6n.1p.115 }\end{array}$

\begin{abstract}
This study attempted to investigate the extent to which two types of pragmatic instruction -explicit versus implicitaffect learners' knowledge in terms of their awareness and production of request strategies. Thirty students with the same level of proficiency were divided into two groups (explicit and implicit). They were exposed to listening excerpts taken from the book Tactics for Listening, with the focus on request making strategies. While the explicit group was equipped with direct awareness-raising tasks and written metapragmatic explanations on the use of appropriate requests, the implicit group was provided with a set of implicit awareness-raising tasks. Outcomes of the study demonstrate that pragmatic instruction of requesting improved learners' awareness of both groups. Also an improvement of learners' production of requests did take place in both groups after the interventional period. However, the explicit group outperformed the implicit one as far as production of request making was concerned.
\end{abstract}

Keywords: Pragmatic competence, Speech acts, Requests, Explicit/Implicit pragmatic instruction

\section{Introduction}

Pragmatics, one important component of the study of human language, is an exciting and fast growing field of today's applied linguistics that many foreign and second language teaching systems in recent decades consider it as an inseparable part of their organizing principles, since it is concerned with the study of meaning. But beyond this simple statement, there are lots of different definitions that "may range from the informal concept (what people mean rather than what they say) through formal (meaning in use rather than literal meaning) to the most technical one (the study of meaning minus truth conditions)" (Chapman, 2011, p. 1). Stalnaker (1972) introduces pragmatics as an intersection of second language knowledge and the context in which it is used. Also Searle (1979) notes that the most influential and dominant field in this intersection is the study of speech acts -one important area of pragmatics in which learners of foreign language differ from native speakers (hereafter NS) in terms of production of pragmatics. Regarding this difference between learners and NSs, the role of pragmatic instruction is supported by investigators. Rose and Kasper (2001) point out that gaining dominance in L2 pragmatics cannot be achieved unless we pay credit and attention to instruction at the level of pragmatics. Studies in second language contexts suggest that instruction is both necessary and effective (Bardovi-Harlig \& Hartford, 1993; Bouton, 1994). Besides, in foreign language contexts, the findings show learners who receive instruction of pragmatics are at a higher level of pragmatic proficiency. The results obtained by Oleshtain and Cohen (1990) and Safont (2005) confirm Schmidt's (1993) hypothesis, since they show how instruction of different aspects of pragmatics can promote learners' pragmatic knowledge. According to Kasper and Rose (2001), EFL learners face several problems in terms of learning pragmatic due to intercultural differences between their own language and the target one. In addition, an EFL context has limited opportunities for learning speech acts and pragmatic input compared with an ESL environment. The reason is that students cannot regularly be exposed to the reallife like context. Rose (1999) points out that even in large classes, there is limited contact and little chance for applying such those useful strategies. This may hinder the process of pragmatic learning. Moreover, Bardovi-Harlig and Hartford (1996) point out the speech act that teachers present to students may be status-bound and consequently could not serve as direct sample for the learners. Rose (1997, 2000), Grant and Starks (2001) and Washburn (2001) discussed that both pragmalinguistic and sociopragmatic awareness are particularly difficult for those studying in an EFL context, because 
there are no extra opportunities outside the classroom for learners to attend in order to develop their pragmatic knowledge. Also as Bardovi-Harlig (1996) notes, some differences between NSs and NNSs in terms of pragmatic production make the role of instruction more salient. In other words, in order for learners to make their pragmatic knowledge more similar to that of NSs, it is necessary to have interventional courses during which L2 learners can benefit from authentic and native-like opportunities. Considering these problems, Kasper (1996) mentions three conditions for the acquisition of pragmatic knowledge: "there must be pertinent input, the input must be noticed and the learners need ample opportunity to develop a high level of control" (p.148), and later supplying the suitable feedback was added to these three conditions by Kasper (2001). In L2 pragmatics instruction, such input that was mentioned by Kasper (2001) can be provided from different sources, including textbooks, films, and audio scripts. For language teachers, the most easily and available pragmatics materials are textbooks. However, some textbooks do not present realistic and naturalistic interactions. For example, in an investigation by Bardovi-Harlig, Hartford, Mahan-Taylor, Morgan and Reynolds (1991) only twelve of twenty textbooks were found to introduce complete closings involving shutting down the topic, preclosing, closing and terminal exchanges. Schmidt's (1993) noticing hypothesis argues that in order for acquisition to take place, L2 learners need to operate on two levels of awareness-noticing and understanding. According to Schmidt, noticing refers to "registering the simple occurrence of some event" (p. 26), a process required for all types of learning to be happened. Another is understanding which refers to "recognition of a general principle, rule, or pattern" (p. 26). From Schmidt's point of view, the acquisition of L2 pragmatics includes not just the input in general that must be attended to (noticing), but also "whatever features of the input play a role in the system to be learned" (understanding) (p. 35). Suitable pragmatic input, therefore, cannot be provided by teacher-talk, classroom or even textbooks. The reason is that these sources are not authentic, representative and native-like to teach. Thus presenting authentic and valuable language is the main responsibility of foreign language instruction (Williams, 1988; Rose, 1993; Bouton, 1996). Using authentic audio/visual material has been reported to be helpful for developing students' both pragmatic knowledge and use. Investigations by Rose (1997, 2000), Grant and Starks (2001) and Washburn (2001) claim that authentic audio-visual input facilitates the process of pragmatic learning in different contexts. Alcon (2005) argues that in EFL contexts, learners can benefit from audio-visual material by being provided some real-life opportunities of pragmatics which they have never been exposed to. In other words, Alcon (2005) believes that dealing with authentic pragmatic tasks prepare learners to interact in target culture. As Kasper and Rose (2001) mention, it is not likely to be one approach preferred over all others in each situation. In fact, many approaches may be appropriate for different pragmatic learning targets, students' characteristics, institutional and sociocultural contexts. However, there are two parallel approaches for teaching pragmatics that were of the most adopted by instructors: explicit versus implicit instruction. Moreover, Alcon (2005) mentions that the explicit and planned instruction is reported to be more beneficial in House and Kasper (1981), House (1996), Rose and Ng Kwai-Fun (2001) and Takahashi (2001). In House and Kasper's (1981) study, German university students of EFL were divided into two groups-explicit and implicit- to receive two different types of instruction focusing on gambits and discourse markers. While both groups were provided with relevant input, some metapragmatic instruction was presented only to the explicit group, but the implicit one did not receive any kind of metapragmatic explanation. The results showed an advantage in favor of the explicit group, although both groups improved after the interventional period. Also House (1996) examined the effect of two different instruction of pragmatic fluency on two explicit and implicit groups. The outcomes of the study indicated that both groups were successful to develop their pragmatic fluency, but the explicit group outperformed the implicit one in applying a wider range of strategies. Similar findings are reported in Rose and $\mathrm{Ng}$ Kwai-Fun (2001), since two different approaches were used by the investigators-deductive versus inductive- to teach compliments and compliment responses. Just like above-mentioned studies, students in the deductive group received metapragmatic explanation while learners in the inductive group did not. In Takahashi's (2001) study, the impact of four input enhancement were compared to see how these four (explicit instruction, NS learners request comparison, NS-NNS request comparison, and reading comprehension) would affect Japanese students' ability of request making. The finding of the study indicated that the explicit teaching was more effective than the others. Identically, Alcon (2005) reported an advantage for the explicit group in comparison with implicit and control group, as far as request making was concerned. While both treatment groups (explicit and implicit) improved after the instructional course, students in the control group were not able to develop their pragmatic knowledge in terms of neither awareness nor production of requests. Also the explicit group outperformed the implicit one by receiving some metapragmatic explanation.

Although the above-mentioned studies showed that the explicit instruction seems to be more effective than the implicit one, a few investigations that studied the effectiveness of implicit instruction led to inconclusive outcomes. Fukuya and Clark (2001) divided ESL students into three groups; focus on forms, focus on form and a control group. While focus on forms group received explicit instruction of mitigating request, implicit group was provided with typographical techniques of mitigators. The results of the study did not demonstrate significant differences among the three groups in terms of pragmatic recognition. The researchers mentioned that different operationalization of input enhancement may change the result. In Martinez-Flor's (2004) study, the effect of explicit, implicit and zero instruction of suggestion was examined on three groups of explicit, implicit and control. Two different teaching approaches were applied by the author; implicit teaching consisted of input enhancement and recast, and the explicit instruction included direct explanation of suggestion. Based on the results, both treatment groups outperformed the control one, but no significant differences were reported between implicit and explicit groups in terms of awareness and production of suggestion.

In line with previous studies, which applied two approaches (explicit versus implicit, and deductive versus inductive) on 
acquisition of different speech acts of pragmatics, our study was an investigation to discover whether the implicit and explicit instruction have any effect on Iranian EFL learners' ability to comprehend and produce pragmatic strategies of request making. Considering the previous research studies, the following research questions are going to be investigated in the current study:

- Does explicit instruction of pragmatics significantly raise the level of the pragmatic awareness of Iranian EFL learners?

- Does explicit instruction of pragmatics significantly improve the pragmatic level of Iranian EFL learners' production?

- Does implicit instruction of pragmatics significantly raise the level of the pragmatic awareness of Iranian EFL learners?

- Does implicit instruction of pragmatics significantly improve the pragmatic level of Iranian EFL learners' production?

- Is there any significant difference between the effectiveness of explicit and implicit instruction on learners' awareness of pragmatics?

- Is there any significant difference between the effectiveness of explicit and implicit instruction on learners' production of pragmatics?

\section{Method}

The Method section describes in detail how the study was conducted, including conceptual and operational definitions of the variables used in the study, Different types of studies will rely on different methodologies; however, a complete description of the methods used enables the reader to evaluate the appropriateness of your methods and the reliability and the validity of your results, It also permits experienced investigators to replicate the study, If your manuscript is an update of an ongoing or earlier study and the method has been published in detail elsewhere, you may refer the reader to that source and simply give a brief synopsis of the method in this section.

\subsection{Participants}

This study included 31 students, between the ages of 39 to 47, studying at Melal EFL Institute and all were intermediate students. All of them were females who have been learning English for three or four years and their level of proficiency was similar. Although the students' level of proficiency was determined by the scores obtained from placement test of the institute, the researcher herself administered the Nelson Proficiency Test (series 250 A) to ensure the homogeneity of the participants. Among 44 participants involved in the Nelson Proficiency Test, $\underline{31}$ students whose scores were between one standard deviation below and above the mean score were considered as acceptable participants and kept to be assigned into one of the two groups (explicit and implicit) randomly for the study. During the instructional period, one of the participants quit attending the class, so the researcher continued the treatment with 30 students.

\subsection{Instrumentation and Procedures}

First, it should be mentioned that the experimental groups had the treatment within 15 sessions. Each session lasted about one hour and thirty minutes, from which about 30 minutes was allocated to the treatment. During the study, both groups were exposed to excerpts taken from the textbook Top Notch 1B (Saslow and Ascher, 2007) and another textbook Tactics for Listening (Richards, 2003) with the focus on requests in 15 sessions. Also the book "Communicating in English, 1" (Matreyek, 1990) was applied as treatment for the explicit group to provide some metapragmatic explanation. The details of the steps taken to collect the data for this study are as follows.

Participants of both groups took the pre-test in session 1. The pre-test lasted for about 30 minutes which was divided into two parts; part A and part B. Part A was based on the awareness of request making in listening. To measure learners' awareness of requests, they were exposed to listening excerpts taken from the textbook Tactics for Listening (Richards, 2003) once, and while they were listening to the same extracts for the second time, they were provided with the scripts of the extracts, so they were able to read and listen to the extracts at the same time. Finally, they were asked to identify and underline the phrase or phrases in their handouts which used to ask people to do something. Participants had to mention 10 phrases related to request making. Each phrase that was underlined correctly had one score. It has to be mentioned that some listening extracts had more than one request phrases to be underlined, and, some others did not have any phrases related to request making at all. This activity was considered as a measurement of their awareness of requests in the pre-test.

Part B was devoted to the production of requests. To measure students' production of requests, the researchers used the DCT of Jalilifar's (2009) study which proved as a reliable data collection tool in the Iranian EFL context. Also Mahani (2012) applied the same DCT in her cross-sectional investigation of Iranian EFL learners' realization of request speech acts. The DCT comprises 24 situations, each of which is followed by a blank space in which the participants were asked to write a request accordingly. Out of 24, 10 situations were chosen to measure the learners' production of requests in the pre-test. Each item had one score, half of which was considered for the correctness of form, and the other half for appropriateness of the context. The total score of the pre-test was 20; 10 scores for awareness, and 10 scores for production of requests (See Appendix A for activities used for pre-test).

During sessions 2 to 14, the two experimental groups received two different types of treatment focusing on the awareness and production of requests in different situations. 
- Instructional activities for the explicit group

At first some excerpts of the book Tactics for Listening (Richards, 2003) were presented for the students. Then, the scripts of the same listening excerpts were handed out in order to enable learners to follow sentence by sentence while they were listening to the excerpts once again. After some explicit awareness-raising tasks, the students were asked to complete DCTs by considering recent information. At last the learners were provided with possible answers to the DCTs and metapragmatic explanations for their self-correction. Also after each unit of the textbook Top Notch $1 B$ (Saslow and Ascher, 2007), they had to review the unit and search for the request making phrases (see Appendix B for a sample of activities assigned for the explicit group).

- Instructional activities for the implicit group

A similar explicit method was used for the implicit group. The same listening excerpts which were chosen for the explicit group were also presented for the implicit one, followed by giving the learners the scripts of them. Next, instead of providing explicit awareness-raising information, the students in this group were provided with implicit awarenessraising tasks. After the students completed the DCTs, the plausible answers to those DCTs were given for the selfcorrection. Finally, at the end of each unit of the book Top Notch 1B (Saslow and Ascher, 2007), the instructor asked the learners to review the previous unit to find and underline request phrases. But no metapragmatic explanations were provided for this group (see Appendix C).

Session 15 started with the posttest; in fact, students were asked to identify a phrase or phrases used for asking a request from the listening excerpts and underline them in their handouts. This activity was considered as a measurement for their awareness of requests. Similar to the pre-test, this part had 10 request phrases to be mentioned and, consequently, 10 scores altogether. To measure the learners' production of requests, they were asked to response 10 situations, each one had one score. The total score of the posttest was 20 as well as the pre-test (see Appendix D for activities used for the posttest).

Students' responses related to part B (production of requests) from both the pre-test and posttest were given to two raters in order to be scored. The two raters are native speakers and live in the United States. They were asked to assess the responses considering two factors: social distance of interlocutors and size of the favor (Alcon, 2005). Also each response has been scored in terms of correctness of form and appropriateness of context (Azis, 2012). The inter-rater reliability of pre-test and posttest was calculated by using Hatch and Lazaraton's (1991) formula. The amount of correlation coefficient due to the pre-test for the explicit and implicit group was calculated 0.74 and 0.67 respectively. Consequently, using Hatch and Lazaraton's (1991) formula, the inter-rater reliability for explicit and implicit groups was computed as 0.85 and 0.80 , respectively. Similarly, the value of correlation coefficient and inter-rater reliability due to posttest for the explicit group was calculated as 0.71 and 0.83 , and for the implicit one 0.72 and 0.82 , respectively.

\section{Result}

To understand the effect of instruction on the two explicit and implicit groups, we compared the pre-test and the posttest of each group in both pragmatic awareness and production. Table 1 pictures information related to the explicit group in terms of its pre and posttests on awareness. T-test analysis reported a difference between the pre-test and the posttest as significant level value $=.000$ denotes that the difference is significant.

Table 1. Paired samples statistics of explicit group, awareness

\begin{tabular}{lcccc}
\hline Test & Mean & N & SD & Std. Error Mean \\
Pre-awareness & 8.067 & 15 & 1.3345 & .3446 \\
Post-awareness & 9.8000 & 15 & .4104 & .10690 \\
\hline
\end{tabular}

Table 2. Paired samples test of explicit group, awareness

\begin{tabular}{lllll}
\hline Group & Test & $\mathrm{T}$ & $\mathrm{df}$ & Significance \\
Explicit & Pre-awareness & -5.030 & 14 & .000 \\
& Post-awareness & & & \\
\hline
\end{tabular}

To examine the second research question, pragmatic production of the explicit group in the posttest over the pre-test was measured by means of paired samples t-test. Table 3 shows an advantage for the posttest over the pre-test in the explicit group, by which hypothesis 2 is rejected, since the results reported in Table 4 demonstrates a significant difference between the pre and posttests. 
Table 3. Paired samples statistics of explicit group, production

\begin{tabular}{lllll}
\hline Test & Mean & N & SD & Std. Error Mean \\
Pre-Production & 5.5000 & 15 & 1.42678 & .36839 \\
Post-Production & 7.1333 & 15 & 1.12546 & .29059 \\
\hline
\end{tabular}

Table 4. Paired samples test of explicit group, production

\begin{tabular}{lllll}
\hline Group & Test & T & Df & Significance \\
Explicit & Pre-production & -7.225 & 14 & .000 \\
& Post-production & & & \\
\hline
\end{tabular}

The third question examines the effectiveness of implicit instruction of pragmatics on learners' pragmatic awareness. Likewise the first research question, by applying a paired samples t-test, the mean scores of the pre-test and posttest were compared. As is shown in Table 5, there is a difference between the two tests in favor of the posttest. Table 6 illustrates that the difference regarding awareness ability of the implicit group is statistically significant.

Table 5. Paired samples statistics of implicit group, awareness

\begin{tabular}{lllll}
\hline Test & Mean & $\mathrm{N}$ & $\mathrm{SD}$ & Std. Error Mean \\
Pre-awareness & 8.0000 & 15 & 1.00000 & .25820 \\
Post-awareness & 9.4000 & 15 & .82808 & .21381 \\
\hline
\end{tabular}

Table 6. Paired samples test of implicit group, awareness

\begin{tabular}{lllll}
\hline Group & Test & T & Df & Significance \\
Implicit & Pre-awareness & -4.010 & 14 & .001 \\
& Post-awareness & & & \\
\hline
\end{tabular}

In order to evaluate the impact of the implicit instruction on students' production of requests, a paired samples t-test was conducted to test the fourth hypotheses made on the basis of the research question 4. As can be seen in Table 7, it is concluded that learners did better on their posttest in terms of production of requesting. The result of t-test indicates the significant difference between students' performance on the pre and posttests.

Table 7. Paired samples statistics of implicit group, production

\begin{tabular}{lllll}
\hline Test & Mean & N & SD & Std. Error Mean \\
Pre-production & 5.7333 & 15 & 1.49841 & .38689 \\
Post-production & 6.1000 & 15 & 1.46629 & .37859 \\
\hline
\end{tabular}

Table 8. Paired samples test of implicit group, production

\begin{tabular}{lllll}
\hline Group & Test & T & Df & Significance \\
Implicit & Pre-production & -6.205 & 14 & .000 \\
& Post-production & & & \\
\hline
\end{tabular}

Results related to questions 1 to 4, seem to confirm previous studies (Olshtain and Cohen, 1990; Morrow, 1995; Alcon, 2005; Safont, 2005), since all reported a positive impact of instruction (of any type) on pragmatic learning. Both treatment groups promoted their pragmatic competence interms of awareness and production of requesting by receiving some related instruction.

To evaluate question 5, which is a comparison between posttests of the two explicit and implicit groups in their awareness ability of requesting, an independent samples t-test was run to see which type of instruction (explicit versus implicit) proved more effective. As pictured in Table 9, although the mean value of the post-awareness related to the explicit group is higher than that of the implicit one, Table 10 demonstrates that this difference is not significant since the value of Sig. (2-tailed) is 0.109 which is not less than 0.05 . It means that, although both implicit and explicit instruction promoted learners' level of awareness in the speech act of requesting, there is not a significant difference by using any kind of these two types of instruction. 


\begin{tabular}{lcccl} 
Table 9. Independent samples statistics of posttests, awareness \\
\hline Test & Mean & N & SD & Std. Error Mean \\
Post-awareness-implicit & 9.400 & 15 & .8281 & .2138 \\
Post-awareness-explicit & 9.800 & 15 & .4140 & .1069 \\
\hline
\end{tabular}

Table 10. Independent samples test of posttests, awareness

\begin{tabular}{lllll}
\hline Group & Test & Sig. & df & Sig.(2-tailed) \\
Implicit & Post-awareness & .001 & 20.58 & .109 \\
Explicit & Post-awareness & & & \\
\hline
\end{tabular}

Results related to question 5, seem to confirm previous investigation of Fukuya et al. (1998), in which it was claimed that the implicit instruction has no priority over the explicit one in promoting learners' awareness of pragmatics. However, the current study seems not to support Kubota's(1995) study in which the implicit instruction of conversational implicature showed an advantage over the explicit one in terms of learners' comprehension of pragmatic features.

Regarding our last research question, which claimed that there is not a significant difference between participants' performance in their production of requesting, an independent samples t-test was run to compare two posttests in learners' production. As Table 11 illustrates, the results related to students' production in the two posttests were significantly different in favor of the explicit group, since significant level (2-tailed) $<0.05$. It means that, the implicit and explicit groups did not act equally in the production of requesting. Rather, the explicit group outperformed the implicit one as far as production is concerned.

Table 11. Independent samples statistics of posttests, production

\begin{tabular}{lllll}
\hline Test & Mean & N & SD & Std. Error Mean \\
Post-production-implicit & 6.1000 & 15 & 1.46629 & .37859 \\
Post-production-explicit & 7.6333 & 15 & .91548 & .23637 \\
\hline
\end{tabular}

Table 12. Independent samples test of posttests, production

\begin{tabular}{lllll}
\hline Group & Test & Sig. & df & Sig.(2-tailed) \\
Implicit & Post-production & .093 & 28 & .002 \\
Explicit & Post-production & & & \\
\hline
\end{tabular}

In line with previous studies investigated by House and Kasper (1981), Takahashi (2001), Rose and NgKwai-Fun (2001), Alcon (2005), our research shows that both types of instruction (explicit versus implicit) improve learners' pragmatic knowledge and production, but it seems that the explicit instruction benefits students' production of requests more than the implicit one. However, taking into account the study conducted by Martinez-Flor (2004), our findings are notin line with his research, in terms of production aspect of pragmatic learning, This difference may be due to providing the explicit group in our study with metapragmatic explanations that affected the related results. In addition, the explicit group in Martinez-Flor's (2004) study received some explanations presented by the teacher, whereas in this study, students were provided with written explanation on request strategies. These reasons were also mentioned in Rose and Ng Kwai-Fun's (2001) and Alcon's (2005) studies, since in their studies two treatment groups (deductive versus inductive in the former and explicit versus implicit in the latter), were compared and results of both groups indicated an advantage for the deductive/explicit over the inductive/implicit one.

Table 13. The capitals, assets and revenue in listed banks

\begin{tabular}{llll}
\hline & Total capital stock & Income of main business & Total assets \\
\hline Pudong Development Bank & 39.2 & 214.7 & 5730.7 \\
\hline Bank of China & 459.4 & 3345.7 & 59876.9 \\
\hline
\end{tabular}

\section{Final remarks and pedagogical implications}

As Schmidt (1993) notes, learning does not take place unless whatever is presented to learners as input becomes intake through awareness at the level of noticing. According to Doughty (2001), learning of different features of pragmatics involves noticing, practicing and storing the input in long-term memory. Since Alcon (2005) believes that learning will 
not take place without attention, in the present study, the students were provided with some relevant inputs to get their attention to the pragmalinguistic and sociopragmatic aspects of requesting. By practicing and memorizing the new knowledge, learners showed an improvement in both awareness and production posttests.

Regarding the research questions, the first question addressed whether explicit instruction of pragmatics raises the level of pragmatic awareness of the learners or not. The results showed that the explicit instruction increases the learners' ability to comprehend and understand request strategies. The second research question addressed whether the explicit instruction of pragmatics raises the level of pragmatic production of the learners or not. It can be claimed that explicit instructions had a remarkable effect on the learners' ability to make requests. The third and fourth research questions were about whether implicit instruction affected learners' awareness and production of pragmatic strategy of requesting. It can be concluded that the implicit instruction increases the ability of learners in understanding and producing the speech act of requesting. Learners' production of requests in the two groups was measured by means of WDCTs, considering appropriate use of form and context and taking into account two factors: social variable and size of the favor (Alcon, 2005). Both groups significantly experienced an improvement in terms of use and awareness of pragmatic strategies after the instructional period. Following Rose's (1997) suggestion, the pragmatic competence consists of knowledge of a pragmatic system and knowledge for its appropriate use. The results of this study confirm that instruction affects and improves learners' knowledge and production of speech act of requesting. Focusing on learners' gain in awareness, the gathered data seemed to support Schmidt's (1993) hypothesis, in that instruction promotes learning, since it makes some aspects of pragmatics (requesting) more noticeable to learners. In addition, in order for the researchers to understand which type of instruction (explicit versus implicit) affected more, they compared the gains in awareness as well as production in the explicit and implicit groups. Although the gains of production were significantly different in favor of explicit over the implicit one, the comparison indicated that there was no significant difference between learners' gain as far as the awareness of requesting was concerned. But both groups showed an increase in learners' awareness of requests.

Although this study was limited in scope and time, the outcomes obviously confirm previous studies on teaching different aspects of pragmatics and found that pragmatic instruction of any kind affects its learning positively. Earlier investigations conducted by House and Kasper (1981), House (1996), Tateyama et al. (1997), and Alcon (2005) compared two different types of instruction (explicit versus implicit/ deductive versus inductive) and have demonstrated that many aspects of learners' pragmatic can be improved by instruction. Also the outcomes of the DCTs in the present study support Rose and Kasper's (2001) claim in that "although inductive and deductive instruction may both lead to gains in pragmalinguistic proficiency, only the latter may be effective for developing sociopragmatic proficiency" (p. 167).

Considering the findings of this study, some pedagogical implications may be proposed; first, second/foreign language learners' pragmatic competence is improved by awareness-raising tasks and metapragmatic explanations. This seems to be more beneficial for foreign language learners, for whom the instructional contexts are in need of authentic and reallife inputs. Also outside of the class, there is no opportunity for foreign language learners to acquire different aspects of language naturally.

Second, different teaching methods should be implemented by teachers to test the effectiveness of each on learning processes. Moreover, teachers by providing authentic audio/video input in the instructional environments can familiarize students with the rules and common norms which are used in natural contexts.

Third, study of speech acts (requesting, apologizing, complaining and complimenting), as the most important field of pragmatics, should be considered and implemented in syllabus design more seriously, since learners have to become aware of language use as well as language usage. Students by learning this field of pragmatics and applying it appropriately, may reduce serious communicative misunderstandings resulted by pragmatic errors, which may be considered offensive from native speakers' point of view. The results of the present study could also make a number of suggestions for future studies. This investigation can be done to examine the effect of explicit versus implicit instruction on learners' ability to apply any other speech acts of pragmatics. Moreover, only female learners participated in this study. Both male and female students can be included as participants in future investigations. In addition, age factor can be considered in future studies. Also, in this study only one level of proficiency was considered, i.e., intermediate; future studies can examine the role of instruction of any speech acts on learners with different levels of proficiency. What is more, the present research - because of some limitations - was done on a small sample of participants. Large samples reduce potential bias and are more generalizable to real population. Finally, future studies can make use of delayed posttest in order to realize whether the effects of explicit and implicit instructions are retained after a while in future. Institutional limitations in administering delayed posttests cannot be ignored, though. Since there is a lot to say about pragmatics in the frame of foreign language learning, future studies can benefit from many other suggestions as well as the few mentioned ones.

\section{References}

Alcon, E. (2005). Does instruction work for learning pragmatic in the EFL context? System, 33(3), 417-435.

Bardovi-Harlig, K. (1996). Pragmatics and language teaching: Bringing pragmatics and pedagogy together. In L.F. Bouton, (Ed.), Pragmatics and language learning, (pp. 21-39). University of Illinois, Urbana- Champaign, Urbana, IL.

Bardovi-Harlig, K., Hartford, B. (1993). Learning the rules of academic talk: A longitudinal study of pragmatic 
development. Studies in Second Language Acquisition, 15, 279-304. doi: 10.1017/S0272263100012122

Bardovi-Harlig, K., Hartford, B. (1996). Input in an institutional setting. Studies in Second Language Acquisition, 18, 171-188. doi: $10.1017 / \mathrm{S} 027226310001487 \mathrm{X}$

Bardovi-Harlig, K., Hartford, B., Mahan-Taylor, R., Morgan, M. J., \& Reynolds, D.W. (1991). Developing pragmatic awareness: Closing the conversation. ELT Journal, 45 (1), 4-15. doi:10.1093/elt/45.1.4

Bouton, L. (1994). Can NNS skill in interpreting implicature in American English be improved through explicit instruction? -A pilot study. In L. Bouton (Ed.), Pragmatics and Language Learning (pp.88-109). Division of English as an International Language Intensive English Institute, University of Illinois, Urbana-Champaign, Urbana, IL.

Bouton, L. (1996). Pragmatics and language learning. In L. Bouton (Ed.), Pragmatics and language learning, monograph series (pp. 1-20). Urbana-Champaign: Division of English as an International Language, University of Illinois, Urbana-Champaign.

Chapman, S. (2011). Pragmatics. New York: Palgrave Macmillan.

Doughty, C. (2001). Cognitive underpinnings of focus on form. In P. Robinson (Ed.), Cognition and second language instruction (pp. 206-257). Cambridge: Cambridge University Press.

Fukuya, Y. J., \& Clark, M. K. (2001). A comparison of input enhancement and explicit instruction of mitigators, In L. Bouton, (Ed.), Pragmatics and Language Learning (vol. 10, pp.111-130). Division of English as an International Language Intensive English Institute, University of Illinois, Urbana-Champaign, Urbana, IL.

Fukuya, Y. J., Reeve, M., Gisi, J., \& Christianson, M. (1998). Does Focus on Form Work for teaching sociopragmatics? Paper presented at the $12^{\text {th }}$ International Conference on Pragmatics and Language Learning, University of Illinois at Urbana-Champaign. (ERIC Document Reproduction Service No. ED 452736).

Grant, L., \& Starks, D. (2001). Screening appropriate teaching materials: Closing from textbooks and television soap operas. International Review of Applied Linguistics, 39, 39-50. doi: 10.1515/iral.39.1.39

Hatch, E., Lazaraton, A. (1991). The research manual: Design statistics of applied linguistics. New York: Newbury House Publishers.

House, J. (1996). Developing pragmatic fluency in English as a foreign language. Studies in Second Language Acquisition, 18, 225-253.

House, J., \& Kasper, G. (1981). Zur Rolle der Kognition in Kommunikationskursen. [The role of cognition in communication courses] Die Neueren Sprachen, 80, 42-55.

Jalilifar, A. (2009). Request strategies: Cross-sectional study of Iranian EFL learners and Australian native speakers. English Language Teaching, 2 (1), 46-61. doi: 10.5539/elt.v2n1p46

Kasper, G. (1996). Introduction: Pragmatics in SLA. Studies in second Language Acquisition,18, 145-148. doi: $10.1017 / \mathrm{S} 0272263100014856$

Kasper, G. (2001). Four perspectives on L2 pragmatic development. Applied Linguistics, 22(4), 502-530. doi: 10.1093/applin/22.4.502

Kasper, G., \& Rose, K. (2001). Research methods in pragmatics. Mahwal, NJ: Lawrence Erlbaum.

Kubota, M. (1995). Teachability of conversational implicature to Japanese EFL learners. The Institute for Research in Language Teaching Bulletin, 9, 35-67.

Mahani, S, T. (2012). A cross-sectional study of Iranian EFL learners' realization of request speech acts. Unpublished Master's thesis, Eastern Mediterranean University, Cyprus.

Martinez-Flor, A. (2004). The effect of instruction on the development of pragmatic competence in the English as a foreign language context: A study based on suggestions. Unpublished Doctoral Dissertation. Universitat Jayme I, Castellon, Spain.

Matreyek, W. (1990). Communicating in English: Examples and Models. Prentice Hall, UK.

Morrow, C. K. 1995. The pragmatic effects of instruction on ESL learners' production of complaint and refusal speech acts. Unpublished Doctoral dissertation, State University of New York, Buffalo.

Oleshtain, E., \& Cohen, A. D. (1990). The learning of complex speech act behavior. TESL Canada Journal, 7 (2), 45-65.

Richards, J. C. (2003). Tactics for listening. Oxford: Oxford University Press.

Rose, K. R. (1993). Sociolinguistic consciousness-raising through video. Language Teacher, 17, 7-9.

Rose, K. R. (1997). Pragmatics in the classroom: Theoretical concerns and practical possibilities. In: L. F. Bouton (Ed.), Pragmatics and Language Learning (Vol 8, pp. 267-295). University of Illinois, Urbana-Champaign, Urbana, IL.

Rose, K. R. (1999). Teachers and students learning about requests in Hong Kong. In: E. Hinlke (Ed.), Culture in Second Language Teaching and Learning (pp. 167-180). Cambridge University Press, Cambridge.

Rose, K. R. (2000). An exploratory cross-sectional study of interlanguage pragmatic development. Studies in Second Language Acquisition, 22, 27-67. doi: 10.1017/S0272263100001029

Rose, K. R., \& Kasper, G. (Eds.). (2001). Pragmatics in Language Teaching. Cambridge: CUP. 
Rose, K. R., \& Ng Kwai-Fun, C. (2001). Inductive and deductive teaching of compliments and compliment responses. In: K. R. Rose, \& G. Kasper (Eds.), Pragmatics in Language Teaching (pp. 145-170). Cambridge University Press, Cambrigde.

Safont, M. P. (2005). Third language learners: Pragmatic production and awareness. Multilinguals Matters, Clevedon.

Saslow, S., \& Ascher, A. (2007). Top notch. Pearson Education, NY.

Schmidt, R. (1993). Consciousness, learning and Interlanguage pragmatics, In: G. Kasper and S. Blum-Kulka (Eds.), Interlanguage Pragmatics (pp. 21-42). Oxford University Press, New York.

Searle, J. R. (1979). The classification of illocutionary acts. Language in Society, 8, 137-151. doi: $10.1017 / \mathrm{S} 0047404500006837$

Stalnaker R. C. (1972). "Pragmatics". In D. Davidson \& G. Harman (Eds.), Semantic of natural language (2nd ed., pp. 380-397). Dordrecht, Netherlands: Reidel.

Takahashi, S. (2001). The role of input enhancement in developing pragmatic competence. In: K. R. Rose, G. Kasper (Eds.), Pragmatics in Language Teaching (pp. 171-199). Cambridge University Press, Cambridge.

Tateyama, Y., Kasper, G., Mui, L., Tay, H., \& Thananart, O. (1997). Explicit and implicit teaching of pragmatic routines. In L. Bouton (Ed.), Pragmatics and language learning, monograph series vol. 8 (pp. 163-178). Urbana-Campaign: Division of English as an International Language, University of Illinois, Urbana-Champaign.

Washburn, G. N. (2001). Using situation comedies for pragmatic language teaching and learning. TESOL Journal, 10 (4), 21-26.

Williams, M. (1988). Language taught for meeting and language used in meetings: Is there anything in common? Applied Linguistics, 9, 45-58. doi: 10.1093/applin/9.1.45

\section{Appendices}

Appendix A. Activities used in the pre-test to measure learners' awareness and production of requests.

A) Choose the phrase or phrases used to ask people to do something in the scripted version of the listening you have already listened to. Note that there might be more than one or even no phrase to be mentioned in each conversation.

1) Situation: Air Travel

a) I wonder if I could change my seat.

b) Oh, is there something wrong with it?

a) Well, I can't see the TV screen very well from where I'm sitting. I'm too far away.

b) Oh, I see. Do you mind waiting until all the passengers have boarded the airplane? After everyone is on board, I'll see if I can move you to a different seat.

a) That's fine.

2) Situation: Shopping

a) This is nice. I like the color. Do you have a medium?

b) You're holding a medium right now.

a) Oh, good. Can I try it on?

b) Sure, you can go right in there- behind you.

3) Situation: Party

a) Here we are. Can you turn on the light? My hands are full.

b) Sure.

c) Surprise!

a) Happy anniversary, honey.

d) And I thought you forgot!

4) Situation: City Transportation

a) One ticket to Chicago please.

b) Yeah. Okay. That's \$24.

a) Does this one have a dining car?

b) Yeah, there is dining car and a snack bar. Here's your change.

a) Thanks. 
5) Situation: Cooking

a) Ana, can I ask you something? I'm going to Spain this summer and I want to try something really Spanish. What do you recommend?

b) Oh, paella, of course. You take rice, meat, seafood, vegetables, and all kinds of spices, and you cook it all together in a really huge pan. It's our most famous dish.

a) It sounds great.

b) But if you really like to experience paella, you've got to eat it like the people in Spain do. We like to eat dinners really late at night, like at 9 or 10 o' clock. Then we go out to discos and dance all night.

a) Wow. I can't wait to go!

6) Situation: Apartment Problems

a) I'm having trouble with the neighbors' children. They play their music at all hours of the night. It's terrible. Can you tell them to stop?

b) Oh, they're really nice kids. They've only done it a few times. I don't think it's worth getting upset about.

7) Situation: Phone Message

This is Mr. Kent from St. Alban's School. I'm calling for Tracy's parents. Unfortunately, she has been absent from school again. Could you please call me back to clarify the situation?

8) Situation: Gadgets and Machines

a) That's funny. It isn't working. I keep pushing the button, but it won't take any pictures.

b) Maybe you need more film.

a) No, that's not it. I put in a new roll of film this morning.

b) What about the batteries?

a) Hmm. I guess they're pretty old.

b) That's the problem. The batteries are dead.

a) That must be it.

b) You should replace them.

9) Situation: Apartment Problems

a) The curtains in the living room are really worn out. Do you think you could get us some new ones?

b) Oh, those belonged to the people who were there before you. The apartment doesn't come with curtains. I'm afraid you'll have to get your own.

10) Situation: Party

a) Are they your parents?

b) Yes, they are. Come on over and I'll introduce you to them.

B) Write a dialogue for each of the following situations. In each situation you are making a request to a specific person and you are asking different types of favors.

1-You are trying to study in your room and hear loud music coming from another student's room down the hall. You don't know the student, but you decide to ask him/her to turn the music down. What would you say?

2-You are at a record store with your best friend. There's a CD you really want to buy, but you don't have any money. How do you ask your friend to lend you money?

3-You are studying at home. Your younger brother opens the window and the cold wind blows right into your face and bothers you. You want to ask him to close it. What would you say?

4-You have bought a shirt from a big store for your father, but he doesn't like its color. You decide to go to the clothes store and ask the manager of the store to allow you to exchange the shirt. What would you say?

5-Your friend and you go to a restaurant to eat. You want to order and need to ask the waiter for the menu. What would you say?

6-You are writing your thesis and need to interview the president of a university whom you don't know. You know the president is very busy, but still want to ask her/him to spare one or two hours for your interview. What would you say?

7-For registration you need to fill out a couple of forms. You search all of your pockets and cannot find a pen. You want to ask another student who is sitting next to you in the department hall. What would you say?

8-You were absent last Friday history class that you are enrolled in. So you decide to borrow your friend's notes to catch up with the rest of the class. What would you say to get this friend to lend you the notes? 
9- You are a professor teaching a course in psychology. You want one of the students who are very competent and always contributes to class discussions, to present a paper in a class a week earlier than scheduled. However, midterm exams are next week and she has a heavy course load. What would you say?

10- You really have to take this course in order to graduate, but you found that the course is already closed. So, you decide to ask the professor, whom you don't know, to allow you to take this course. What would you say to get this professor to permit you to participate in this course?

\section{Appendix B}

Appendix B. Examples of some of the activities used with the explicit group

1) Read the following information about making requests, then, find an example of this type of request in the printed version of Tactics for listening excerpts.

- When you ask someone to do something for you, it's important to sound polite. Especially, when s/he has the higher position. In these occasions, note that you shouldn't use imperative forms. Like:

"Could you open the door for me, please?"

- Imperatives are used to ask people to do something when you have a higher position or both of you know each other very well. For example you ask your close friend to open the window. you say:

"Open the window, Sarah. The weather is too hot here."

- Sometimes people do not make requests directly. In these situations, our realizations of making requests are formed based on the conversation and the context in which requesting takes place.

"Too cold." Means that you ask a person to close the door.

2) Write a request for the following situations:

- Sarah asks a friend to watch her dog for a few hours.

- A man asks another one sitting next to him in a taxi to tell him the exact date of the election.

- A woman calls the waiter to have one more bottle of soda.

\section{Appendix C}

Appendix C: Example of some of the activities used with the implicit group

1) People use different ways to request each other to do something. Based on what you've already listened to, different examples of requests are presented as follows. Find them in the printed version and complete them.

Would you mind if...

I want to...

I would like to...

Please...

2) Make a request for the following situations:

- Sarah asks a friend to watch her dog for a few hours.

- A man asks another one sitting next to him in a taxi to tell him the exact date of the election.

- A woman calls the waiter to have one more bottle of soda.

\section{Appendix D}

Appendix D: Activities used in the posttest to measure learners' awareness and production of requests

A) Choose the phrase or phrases used to ask people to do something in the scripted version of the listening you have already listened to. Note that there might be more than one or no phrase to be mentioned in each conversation.

1) Situation: Restaurant

a) What would you like to order?

b) I think I'll have the fish. And could I have some tea please?

a) Sure.

b) Oh! Could you ask the chef to hurry? I'm really starving.

a) Okay. I'll try to get it for you as soon as possible.

2) Situation: Renting a car

a) City Cabs.

b) Yes, I'd like a cab to the National Museum, please. 
a) Sure, how many passengers are there?

b) There are three of us.

a) And about how much is it to the museum from my hotel- the American Inn, on Fourth Street.

b) It'll be about $\$ 20$. Let me give you your taxi number. It's number 3556 .

a) Thanks.

3) Situation: Restaurant

a) I'd like to try a seafood restaurant today. What do you think?

b) Seafood sounds great. I was going to suggest a pizza, but seafood's a lot better.

4) Situation: Party

a) Hi, Ted.

b) Hi, Lynne.

a) Hey, are you free on Saturday afternoon?

b) Yeah. What do you have in mind?

a) Well, I'm going down to the park with some friends. We're going to grill some steaks down there. Why don't you come?

b) Okay. I'll bring something to drink.

5) Situation: Air Travel

a) Could you put your seat forward now, sir? We're be landing shortly.

b) So soon? Great!

6) Situation: Air Travel

a) Excuse me ma'am?

b) Yes?

a) Let me put your bag in the overhead compartment for you. It's too big to leave under your seat.

b) Oh, okay. Thanks.

7) Situation: Television

a) Do you like magic shows? There's going to be a great one on TV tonight!

b) Well, honestly, I think those shows are really frustrating. I hate trying to figure out how magicians do their tricks.

a) That's so bad. So, I don't want to watch that program with me.

b) No. Definitely not.

8) Situation: Cooking

a) I'm in kind of a hurry today, Luca. Would you mind if we just grabbed a quick lunch at a fast food joint?

b) Oh, man. I would never hear that in Italy.

a) Oh, really? Why is that?

b) Well, long lunches are an important part of Italian culture. I like to meet my friends at a nice restaurant, order some appetizers, and then eat lasagna al forno. That means lasagna cooked in an oven, and after you're done eating, you're not supposed to leave right away. You should sit around for a while, just drinking coffee and chatting.

a) That sounds nice. I wish we could do that here.

9) Situation: Apartment Problems

a) I'm afraid the living room really needs painting. It's been several years since we moved in, and the apartment looks really dirty. Do you think you could get it painted?

b) No, I don't have time right now. But you're welcome to paint it yourself if you want to.

10) Situation: Restaurant

a) What can I get you?

b) I'd like a cheeseburger, French fries, and a cola.

a) Okay.

b) But could you make sure there's no salt on the French fries?

a) No salt? Okay.

b) Thanks. I'm on a salt-free diet.

a) I'll make sure there's no salt on the fries. Don't worry. 
B) Write a dialogue for each of the following situations. In each situation you are making a request to a specific person and you are asking different types of favors.

1-You have a paper due in one of your classes next week. However, you will be very busy this week and don't have any time to write it. You go to your professor's office to ask for more time to write the paper. How do you request an extension?

2-You are a librarian. Today a student is making a noise and disturbing other students. You don't know that student. However, you decide to ask the student to quiet down. What would you say?

3-A friend of yours from out of the town is paying you a visit. Both of you would like to take a photo together to remember this happy moment. You decide to ask a nearby person who is stranger to you, to do this favor. What would you say?

4-You and your friend are members of the college skiing club. You have just arrived at the mountain and see that your friend is applying sunscreen lotion. You want to use that lotion because you have forgotten to bring your own. How would you ask your friend?

5-Your English midterm exam is approaching, and you find that the date of the test is the same as that of your brother's wedding. You decide to ask the professor whom you don't know personally to rearrange another day especially for you to take this test. What would you say?

6-Your mother will be visiting from out of town and you want to pick her up at the airport. However, her flight arrives at 3:00 PM, but you have to work until 5:00 p.m. How do you ask your boss to let you out of work early?

7-You are a teacher. It's the beginning of the semester and you don't know the students yet. In class, the mobile phone of one of your students rings. You want to ask her/him to turn off the mobile phone. What would you say?

8- You are going to visit your friend, who lives in the college dormitory. You are on the campus, but you don't know where the room is? You are going to ask a student for the location of the dorm. How would you ask the student?

9-It's 7:00 a.m. and you want to go to work. You have to leave your daughter alone because her baby sitter is late. You decide to ask your friend, who lives in your neighborhood to take care of your little daughter in the meanwhile. What would you say?

10-You are the manager of a company. You are in a meeting with the other members of your company. You need to write some notes, but you realize that you don't have any paper. You turn to the person sitting next to you and you know her/him very well. What would you say? 